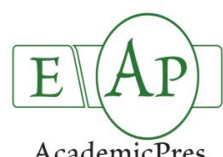

AcademicPres

\title{
Japanese Sweetpotatoes: Production, Cultivars, and Possible Ancestry
}

\author{
Sakio TSUTSUI, Yoshihiko SHIGA, Tetsuo MIKAMI* \\ Hokkaido Agricultural Laboratory for Business Development, Eniwa, 061-1405, \\ Japan;tsutsui@halor.jp;shiga@halor.jp;t-mikami@imb.me-h.ne.jp (*orrespondingauthor)
}

\begin{abstract}
Sweetpotato has recently received much attention due to its many agricultural advantages such as its adaptability to different environmental conditions and its nutritional value. It has been grown in Japan for more than 400 years, and the bulk of the Japanese harvest is presently destined for fresh market consumption as well as for the food and beverage processing industry. This review begins by providing an overview of the commercial production and agronomic characteristics of sweetpotato cultivars in Japan. The paper deals with the possible ancestry of Japanese sweetpotatoes, and finally describes several orange- or purple-fleshed genotypes that are adapted well to cold northern climates and considered as valuable sources for enhancing the physiological functionality of this crop.
\end{abstract}

Keywords: adaptability, breeding, genetic resources, horticultural characteristics, Ipomoea batatas (L.) Lam.

\section{Introduction}

Sweetpotato [Ipomoea batatas (L.) Lam.], a member of the morning glory family Convolvulaceae, ranks as seventh among the most important food crops in the world (Çalişkan et al., 2007; Rossel et al., 2008; Troung et al., 2011; Rodrigues-Bonilla et al., 2014). It is an obligatorily outcrossing crop, but rarely flowers when the daylight is longer than 11 hours, as is normal outside of the tropics (Gurmu et al., 2013; http://schoolswikipedia.org/2006/wp/s/S weet_potato.htm). The crop is generally propagated either by vine cuttings or by sprouts called "slips" that are removed from the tuberous roots (George et al., 2011). The outcrossing nature, combined with clonal propagation has created a vast number of cultivated genotypes around the world (Zhang et al., 1998; Huamán et al., 1999; Elameen et al., 2011; Thiyagu et al., 2013).

It is believed that sweetpotato was first introduced into Japan as early as the beginning of the 17 th century (http://www.nodai.ac.jp/journal/research/suzki_s/0803_01.ht $\mathrm{ml})$. Thereafter the crop became popular in this country because it was a reliable crop in cases of crop failure of other staple foods. While cultivars grown in Japan before the 1920s were mostly direct introductions and landraces, modern cultivars are either the products of controlled crosses or somatic selections of mutants (MAFF, 2015). More than 100 sweetpotato cultivars have been developed by Japanese breeders, but currently sweetpotato culture in the country is dominated by only a few cultivars (MAFF, 2015).

Breeding efforts have been made to develop new sweetpotato cultivars with high yield, resistance to biotic and abiotic stresses, and other characteristics that enhance acceptability by end users (Katayama et al., 2006; Oki et al., 2006; Ishiguro et al., 2010). Having a collection of information about the Japanese sweetpotato germplasm accessions is valuable to researchers and other stakeholders interested in understanding sweetpotato production in Japan. However, the information of interest is scattered among individual scientific reports. This review outlines the current status of Japanese sweetpotato production and the horticultural characteristics of leading cultivars. The paper also focuses on the ancestry of Japanese sweetpotatoes, and the genetic resources potentially useful for enhancing the adaptability and physiological functionality of this crop.

\section{Commercial Production}

Sweetpotato is cultivated throughout tropical and warm temperate regions wherever there is sufficient water to support its growth. According to the $\mathrm{FAO}$ statistics, world production in 2013 exceeded 103 million metric tons (FAO, 2015). The majority came from China, with a production of 70 million tons from 3,358,000 ha. The average sweetpotato production per year during 2010-2014 was ca. 890,000 tons in Japan (Table 1). Almost all of the Japanese harvest is destined for human consumption, in contrast with China where $40 \%$ of the sweetpotatoes harvested is used as animal feed to support an increasing domestic demand for animal protein (Adam, 2005; Statistics of Agriculture, Forestry and Fisheries, 2016). In Japan, the fresh tuberous roots are commonly boiled, steamed, baked or fried to eat them at home. They are also processed to make industrial products such as starch, liquor, flour and food dyes (Katayama et al., 2006). In recent years, the market for sweetpotato as a source of Japanese traditional spirits is growing (MAFF, 2015). 
Table 1. Harvest area and production of sweet potato in Japan

\begin{tabular}{lccccc}
\hline Parameters & 2010 & 2011 & 2012 & 2013 & 2014 \\
\hline Harvest area $($ ha $)$ & 39,700 & 38,900 & 38,800 & 38,600 & 38,000 \\
Production $(\mathrm{t})$ & 863,600 & 885,900 & 875,900 & 942,300 & 886,500 \\
\hline
\end{tabular}

Source: Statistics of Agriculture, Forestry and Fisheries (2016)

\section{Leading cultivars}

In 2012, Japan's sweetpotato growing land area (38,800 ha, see Table 1) consisted mostly of the following cultivars: 'Koganesengan', 22.1\% of total acreage; 'Beniazuma', 19.0\%; 'Kokei 14' and its mutants, 11.4\%; 'Shiroyutaka', 11.0\%; 'Beniharuka', 5.3\%; and 'Benimasari', 2.1\% (MAFF, 2015). Horticultural characteristics of these cultivars are described below.

\section{'Koganesengan'}

This cultivar was derived from a cross between 'Kakei 7-120' and ' $\mathrm{L}-4-5$ (Pelican Processor)', and has been predominantly grown in warmer western Japan. The maternal parent of 'Kakei 7120 ' is an Indonesian landrace, whereas 'Pelican Processor' is a cultivar bred in Louisiana Agricultural Experiment Station, USA. Storage roots of 'Koganesengan' are mostly fusiform and are characterized by their cream-coloured skins and white to light yellow flesh. Mature leaves are cordate and slightly lobed. The release of 'Koganesengan' in 1966 provided consumers and growers with high-yielding and high-starch-content sweetpotato. The cultivar also exhibits moderate resistance to the coffee rootlesion nematode, Pratylenchus coffeae (Zimmermann) Filipjev \& Schuurmans Steckhoven. For many years, it was primarily used as a source of industrial starch. At this present time, however, demand for higher-starch sweetpotatoes declines with the wide availability of inexpensive corn (maize) and cassava starch. 'Koganesengan' is currently the most commonly grown cultivar for the production of Japanese spirits. It is also used for fresh market consumption thanks to its good taste.

\section{'Beniazuma'}

'Beniazuma' was produced by crossing 'Kanto 85 ' as the seed parent with 'Koganesengan' as the pollen parent, and approved for release in 1984. This cultivar has green and cordate leaves, some with slight teeth on the margin. The vines are purple in colour and vigorous, forming a dense canopy. Storage roots are fusiform, lightly grooved, with an attractive purple-red skin and yellow flesh (Fig. 1A). Sprouting of bedded roots is mostly satisfactory. 'Beniazuma' has a dry texture with a sweet taste when cooked, and has been almost exclusively used for fresh market consumption. It is generally favoured in the markets of eastern Japan. 'Beniazuma' is resistant to soil rot caused by Streptomyces ipomoeae (Person \& W.J. Martin) Waksman \& Henrici. The cultivar has also moderate resistance to the southern root-knot nematode, Meloidogyne incognita (Kofoid \& White) Chitwood.

\section{'Kokei 14'}

The cultivar originated from a cross 'Nancy Hall' $\times$ 'Sium', and was officially released in 1945. 'Nancy Hall' is a U.S. cultivar, while the origin of 'Sium' is uncertain. Vine growth is relatively vigorous with green, cordate leaves. Plants form long, fusiform storage roots with a purple-red skin colour and light-yellow flesh colour. 'Kokei 14 ' and its mutants (e.g. 'Miyazakibeni', 'Narutokintoki' and 'Tosabeni'), all of which are mainly utilised for fresh market consumption, have a slightly dry texture and sweet taste upon cooking. These quality attributes are generally preferred by the consumers of western Japan. 'Kokei 14' exhibits early thickening growth of storage roots, making it possible to harvest the crop early. Harvested roots also keep well under long-term storage. 'Kokei 14 ' has intermediate or relatively high level of resistance to the coffee root-lesion nematode.

\section{'Shiroyutaka'}

'Shiroyutaka' is a cultivar for starch production, and has moderate to high level of field resistance to insect pest and disease as well as high storage root yield. It generally yields more than 'Koganesengan'. 'Shiroyutaka' originated from a 1975 cross between 'Kyukei 708-13' and 'S684-6, and was released in 1985. 'Kyukei 708-13' was a source of resistance to the southern rootknot nematode, while 'S684-6 provided resistance to black rot caused by the ascomycete fungus, Ceratocystis fimbriata and coffee root-lesion nematode. This cultivar has spreading vines and vigorous growth. Storage roots are fusiform, and skin colour is pale yellow with pink at both proximal and distal ends. Flesh colour is white to cream.

\section{'Beniharuka'}

'Beniharuka', a cultivar for fresh market consumption, is an attractive purple-red-skinned, cream-fleshed sweetpotato released in 2007. It resulted from hybridization of 'Kyushu 121' with
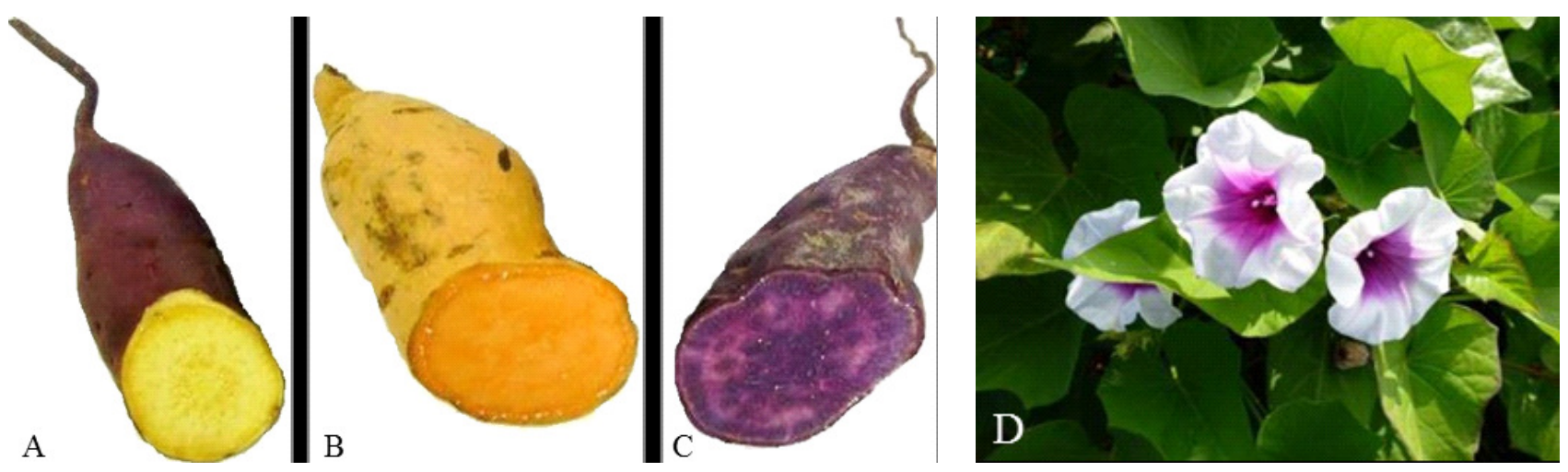

Fig. 1. Root skin and flesh colour of cv. 'Beniazuma' (A), 'Umekei 13' (B) and 'Umekei 15' (C), and the sweetpotato plant in flower (D) (Photo: S. Tsutsui) 
'Harukogane', and demonstrates resistance to the southern rootknot nematode. The cultivar has a somewhat dry texture with a sweet taste when cooked, and is also characterized by good storage quality.

\section{'Benimasari'}

This cultivar originated from a cross of 'Kyushu 104' $\times$ 'Kyukei 87010-21', and is mainly utilized for fresh market consumption. The release of 'Benimasari' in 2001 provided consumers and growers with a pale-yellow-fleshed, attractive red skinned sweetpotato. Mature leaves are cordate and dark green. 'Benimasari' roots store well and have a somewhat moist texture and sweet taste upon cooking. In addition, the cultivar is resistant to black rot and moderately resistant to the coffee root-lesion nematode.

\section{Ancestry of Japanese sweetpotatoes}

The question then arises as to from where and how sweetpotatoes reached Japan. Molecular markers have been extensively used for analysing the genetic diversity and phylogenetic relationships among a wide array of sweetpotato genotypes (Prakash et al., 1996; Zhang et al., 1998, 2004; Dhillon and Ishiki, 1999; Tseng et al., 2002; Elameen et al., 2008). Intriguingly, RAPD (Randam Amplified Polymorphic DNA) analysis of sweetpotato accessions originating from different geographical regions led Gichuki et al. (2003) to conclude that sweetpotato was domesticated in Mesoamerica and then spread to South America (the Peruvian-Ecuadorian region). They also suggested the existence of two distinct genepools (the SouthAmerican and Central American/Caribbean genepools) in the primary centre of diversity.

This theory has subsequently been challenged by Roullier $e t$ al. (2011, 2013a, 2013b) who, using both nuclear and chloroplast microsatellite markers, indicated that sweetpotato was domesticated twice, once in Mesoamerica and the other in the northwestern part of South America. According to linguistic and archaeological studies, sweetpotato could have spread to the Pacific via three different main routes (viz. Kumara, Batata, and Camote lines) (Barrau, 1957; Yen, 1974). The Kumara line represents the transfer of South American sweetpotatoes by Polynesian travelers or chance spread of seeds via ocean currents, from the western coast of South America to Polynesia, between 1000 and $1100 \mathrm{AD}$. The second route (Batata line) is based upon the assumption that the Portuguese explorers of the 16th century introduced sweetpotatoes from the Caribbean and Central America to eastern Indonesis.

Furthermore, Spanish "Acapulco-Manila" galleons are supposed to have introduced the Mesoamerican sweetpotatoes to the Philippines in the 16th century (Camote line), with subsequent dispersal to Japan and China. Actually, the analysis of nuclear and chloroplast microsatellite loci confirmed that the Japanese landraces examined are principally derived from the Central American/Caribbean genepool (Roullier et al., 2013a). In Japan, there have been multiple introductions of breeding materials from different sources (see the description of cvs. 'Koganesengan' and 'Kokei 14') after the initial transmission, which suggests the broadening of genetic diversity. On the basis of DNA marker [RAPD, SAMPL (Selective Amplification of Microsatellite Polymorphic Loci) or ISSR (Inter-Simple Sequence Repeat)] analyses, however, most of modern Japanese cultivars exhibited limited genetic diversity (Komaki et al., 1998; Dhillon and Ishiki, 1999; Tseng et al., 2002; Hu et al., 2003). This may be partly a consequence of selection for the attributes favoured by Japanese consumers and growers as well as of adaptation to the local environment within Japan. In addition, the possibility cannot be ruled out that the sweetpotato genotypes chosen as parents in hybrid breeding so far belong to the same genepool.

\section{Genetic resources and breeding}

Sweetpotato normally grows best at ambient day and night temperatures from 20 to $30^{\circ} \mathrm{C}$ and requires a minimum of five months of frost-free growing conditions (Rossel et al., 2008). It is also noted that the storage roots may sustain chilling injury if they are subjected to temperatures below $10^{\circ} \mathrm{C}$ for even a few hours (Stoddard et al., 2013). In Japan, commercial sweetpotato production is indeed confined to the temperate central and southwestern areas. New sweetpotato cultivars with enhanced tolerance to low temperature would enable this crop species to be cultivated under normally unfavorable culture conditions. Interestingly, some sweetpotato genotypes have recently proven adaptable to colder regions (Tsutsui et al., 2008). As shown in Table 2, five breeding lines were grown in the experimental fields (maximum and minimum air temperatures in the growing season and frost-free period, in 2005 and 2006 , were $33.4^{\circ} \mathrm{C}$, $2.2^{\circ} \mathrm{C}$, and 143 days, respectively) situated in Hokkaido, the northernmost district of Japan, and data were collected for storage root yield and other agronomic traits. These lines produced yields comparable to or exceeding the average national root yield of 2,300 kg/10a (Tables 1 and 2).

Vine cuttings were planted in a row with a between-row distance of $120 \mathrm{~cm}$ and a between-plant distance within the row of $40 \mathrm{~cm}$, giving a population density of 2,083 plants per 10 ares. The ridges were covered with polyethylene film mulch. The plots received 5-10-10 $\left(\mathrm{N}-\mathrm{P}_{2} \mathrm{O}_{5}-\mathrm{K}_{2} \mathrm{O}\right) \mathrm{kg} / 10$ a fertilizer. The harvest time was the beginning or middle of October.

Table 2. Storage root yield and horticultural characteristics of five sweetpotato breeding lines ('Umekei 09' through 'Umekei 15') and cv.

'Beniazuma' when tested at Urausu-chou (432 $6^{\prime} \mathrm{N}, 141^{\circ} 49^{\prime}$ E, ca. $100 \mathrm{~m}$ a.s.l.) in Hokkaido, in 2005 and 2006

\begin{tabular}{|c|c|c|c|c|}
\hline Genotype & Mean for root yield $(\mathrm{kg} / 10 \mathrm{a})$ & Skin colour & Flesh colour & Flowering habit \\
\hline 'Umekei 09' & 2,852 & Pale red & Dark orange & Profuse \\
\hline 'Umekei 10’ & 4,100 & Purple-red & Orange & Moderate \\
\hline 'Umekei 12’ & 4,579 & Red & Orange & Moderate \\
\hline 'Umekei 13' & 3,518 & Orange & Dark orange & Profuse \\
\hline 'Umekei 15' & 4,198 & Dark purple & Dark purple & Moderate \\
\hline 'Beniazuma' & 2,745 & Purple-red & Yellow & Failure of flowering \\
\hline
\end{tabular}

Source: S. Tsutsui et al. (2008) 
The lines have also orange or purple flesh colour (Tsutsui et al., 2008, Table 2, Fig. 1B, C). There has been increasing emphasis in recent years upon the physiological functionality of sweetpotatoes. Breeding efforts do exist to improve the content of functional components such as anthocyanins, ß-carotene, polyphenols, dietary fibres, vitamins and minerals (Katayama $e t$ al., 2006; Oki et al., 2006; Ishiguro et al., 2010). It is certain that sweetpotatoes with orange and purple flesh are rich in B-carotene and anthocyanins, respectively (Oki et al., 2006; Ishiguro et al., 2010; Montilla et al., 2011; Saraswati et al., 2013). Hence, the lines in question are surely valuable as raw materials for developing new sweetpotato cultivars with enhanced functionality as well as with the adaptability to cold climates.

An additional feature of these breeding lines merits comment. Most Japanese sweetpotato cultivars normally fail to flower under the conditions in their main growing regions, and some treatments has been used to induce flowering, including grafting, vine girdling, day-length control and so forth (Lardizabal and Thompson, 1988, 1990). By contrast, the five lines flowered well without grafting and other treatments (Tsutsui et al., 2008, Table 2, Fig. 1D), making them good parents for a sweetpotato breeding programme. In conclusion, a variety of sweetpotato genetic resources should be properly collected and efficiently phenotyped to identify the genotypes necessary for genetic improvement of the crop.

\section{Acknowledgements}

We are grateful to Mr. Makoto Nakamura (Managing Director, Hokkaido Agricultural Laboratory for Business Development) for support throughout this work, and Dr. Yoshiki Umemura and Mr. Katsumasa Fujiwara for valuable comments.

\section{References}

Adam KL (2005). Sweetpotato: organic production. ATTRA Publication http://www.attrancat.org/attra-pub/sweetpotato.html

Barrau J (1957). L'énigme de la patate douce en Océanie. Etudes d'OutreMer 40:83-87.

Çalişkan ME, Sögüt T, Boydak E, Ertürk E, Arioğlu H (2007). Growth, yield, and quality of sweet potato (Ipomoea batatas (L.) Lam.) cultivars in the southeastern Anatolian and east Mediterranean regions of Turkey. Turkish Journal of Agriculture and Forestry 31:213-227.

Dhillon NPS, Ishiki K (1999). Genomic variation and genetic relationships in Ipomoea spp.. Plant Breeding 118:161-165.

Elameen A, Fjellheim S, Larsen A, Rognli OA, Sundheim L, Msolla S, ... Klemsdal SS (2008). Analysis of genetic diversity in a sweet potato (Ipomoea batatas $\mathrm{L}$.) germplasm collection from Tanzania as revealed by AFLP.Genetic Resources and Crop Evolution 55:397-408.

Elameen A, Larsen A, Klemsdal SS, Fjellheim S, Sundheim L, Msolla S, ... Rognli OA (2011). Phenotypic diversity of plant morphological and root descriptor traits within a sweet potato, Ipomoea batatas (L.) Lam., germplasm collection from Tanzania. Genetic Resources and Crop Evolution 58:397-407.

FAO (2015). FAOSTAT database. Retrieved 2016 April 11 from http://faostat3.fao.org/.
George NA, Pecota KV, Bowen BD, Schultheis JR, Yencho GC (2011). Root piece planting in sweetpotato-A synthesis of previous research and directions for the future. Hort Technology 21:703-711.

Gurmu F, Hussein S, Laing M (2013). Self- and cross-incompatibilities in sweetpotato and their implications on breeding. Australian Journal of CropScience 7:20742078.

Hu J, Nakatani M, Lalusin AG, Kuranouchi T, Fujimura T(2003). Genetic analysis of sweetpotato and wild relatives using Inter-simple Sequence Repeats(ISSRs). BreedingScience 53:297-304.

Huamán Z, Aguilar C, Ortiz R (1999). Selecting a Peruvian sweetpotato core collection on the basis of morphological, eco-geographical, and disease and pest reaction data. Theoretical and Applied Genetics 98:840844.

Ishiguro K, Yoshinaga M, Kai Y, Maoka T, Yoshimoto M (2010). Composition, content and antioxidative activity of the carotenoids in yellow-fleshed sweetpotato (Ipomoea batatas L.). Breeding Science 60:324329.

Katayama K, Komae K, Tamiya S, Khoyama K, Nakatani M, Komaki K (2006). Studies on the breeding for improving starch properties in sweet potato.Japan Agricultural Research Quarterly 40:115-122.

Komaki K, Regmi HN, Katayama K, TamiyaS (1998). Morphological and RAPD pattern variations in sweetpotato and its closely related species. BreedingScience 48:281-286.

Lardizabal RD, Thompson PG (1988). Hydroponic culture, grafting, and growth regulators to increase flowering in sweet potato. HortScience 23:993-995.

Lardizabal RD, Thompson PG (1990). Growth regulators combined with grafting increase flower number and seed production in sweet potato. HortScience 25:79-81.

MAFF (Ministry of Agriculture, Forestry and Fisheries, Japan) (2015). Statistics of sweetpotato production (in Japanese). Retrieved 2016 March 11 from http://wrww.maff.go.jp/j/seisan/tokusan/imo/26siryou.btml.

Montilla EC, Hillebrand S, Winterhalter P (2011). Anthocyanins in purple sweet potato (Ipomoea batatas L.) varieties. Fruit, Vegetable and Cereal Science and Biotechnology 5:19-24.

Oki T, Nagai S, Yoshinaga M, Nishiba Y, Suda I (2006). Contribution of $\beta$ carotene to radical scavenging capacity varies among orange-fleshed sweet potato cultivars. FoodScienceand Technology Research 12:156-160.

Prakash CS, He G, Jarret RL (1996). DNA marker-based study of genetic relatedness in United States sweetpotato cultivars. Journal of the American Society for Horticultural Science 121:1059-1062.

Rodriguez-Bonilla L, Cuevas HE, Montero-Rojas M, Bird-Pico F, LucianoRosario D, Siritunga D (2014). Assessment of genetic diversity of sweet potato in Puerto Rico.PLoSONE 9:e116184.

Rossel G, Espinoza C, Javier M, Tay D (2008). Regeneration guidelines: sweet potato. In: Dulloo ME, Thormann I, Jorge MA, Hanson J (Eds). Crop specific regeneration guidelines [CD-ROM]. CGIAR Systemwide Genetic Resource Programme, Rome, Italy.

Roullier C, Rossel G, Tay D, McKey D, Levot V (2011). Combining chloroplast and nuclear microsatellites to investigate origin and dispersal of New World sweet potato landraces. Molecular Ecology 20:39633977. 
Roullier C, Benoit L, McKey DB, Lebot V (2013a). Historical collections reveal patterns of diffusion of sweet potato in Oceania obscured by modern plant movements and recombination. Proceedings of the National Academy of Sciences of the United States of America 110:2205-2210.

Roullier C, Kambouo R, Paofa J, McKey D, Lebot V(2013b). On the origin of sweet potato (Ipomoea batatas (L.) Lam.) genetic diversity in New Guinea, a secondary centre of diversity. Heredity 110:594-604.

Saraswati P, Soplanit A, Syahputra AT, Kossay L, Muid N, GintingE, Lyons $G$ (2013). Yield trial and sensory evaluation of sweetpotato cultivars in Highland Papua and West Papua Indonesia. Journal of Tropical Agriculture 51:7483.

Statistics of Agriculture, Forestry and Fisheries (2016). Sweetpotato crop area and harvest volume. Retrieved 2016 March 25 from http://www.maff.go.jp/j/tokei/kouhyou/sakumotu/sakkyou-kome/.

Stoddard CS, Davis RM, Cantwell M (2013). Sweetpotato production in California. Publication 7237. University of California, Agriculture and Natural Resources Communication Services.

Thiyagu D, Rafii MY, Mahmud TMM, Latif MA, Malek MA, Sentoor G (2013). Genetic variability of sweet potato (Ipomoea batatas Lam.) genotypes selected for vegetable use. Journal of Food, Agriculture \& Environment 11:340-344.
Troung VD, Avula RY, Pecota K, Yencho CG (2011). Sweet potatoes. In: Sinha NK (Ed) Handbook of vegetables and vegetable processing. Wiley-Blackwell,NewJersey,pp 717-737.

Tseng Y-T, Lo H-F, Hwang S-Y (2002). Genotyping and assessment of genetic relationships in elite polycross breeding cultivars of sweet potato in Taiwan based on SAMPL polymorphisms. Botanical Bulletin of AcademiaSinica 43:99-105.

Tsutsui S, Umemura Y, Shiga Y (2008). Hokkaido de ikusei sareta satsumaimo no tokusei, [Agronomic traits of sweetpotato genotypes developed in Hokkaido, Japan]. Proceedings of the Hokkaido Society for Horticultural Research 41:52-53.

Yen DE (1974). The sweet potato in Oceania: An essay in ethnobotany. Bernica P. Bishop Museum 236, Bishop Museum Press, Honolulu, HA, USA.

Zhang D, Ghislain M, Huamán Z, Golmirzaie A, Hijmans R (1998). RAPD variation in sweetpotato (Ipomoea batatas (L.) Lam) cultivars from South America and Papua New Guinea. Genetic Resources and CropEvolution 45:271-277.

Zhang D, Rossel G, Kriegner A, Hijmans R (2004). AFLP assessment of diversity in sweetpotato from Latin America and the Pacific region: Its implications on the dispersal of the crop. Genetic Resources and Crop Evolution 51:115-120. 